МРНТИ 06.73.55

\author{
Аубакирова Ж.Я. ${ }^{1}$, Ердеш Э.Б. ${ }^{2}$ \\ ²д.э.н., професcop, e-mail: aubakyrova.zh@gmail.com \\ ${ }^{2}$ магистрант, e-mail: yerdesh.elmira@bk.ru \\ Казахский национальный университет им. аль-Фараби, Казахстан, г. Алматы

\section{ЦИФРОВАЯ ТРАНСФОРМАЦИЯ: ПЕРЕХОА БАНКОВ К ЦИФРОВИЗАЦИИ И ИННОВАЦИЯМ}

В статье рассмотрены цифровые преобразования, происходящие в финансовой сфере, которые обусловлены современными проблемами и возможностями всей отрасли, касается ли это страхования, розничной торговли, банковских или Аругих финансовых услуг. В то же время, в каждом из этих сегментов финансовой отрасли существует ряд конкретных заАач в зависимости от уровня зрелости цифровой трансформации, гибкой IT-инфраструктуры, общей экосистемы, клиентской базы, вк^ючая использование цифровых каналов, новых хранилищ данных, расширенной аналитики и степени оцифровки данных процессов.

Целью исслеАования является сравнительный анализ и обобщение состояния развития цифровой трансформации в мире, опыт цифровизации банковской системы, выявление проблем и путей их преодоления. Особое внимание уделено современному состоянию и перспективам развития инновационных технологий в банковском секторе экономики Казахстана.

Методология проведенного исследования базировалась на изучении трудов зарубежных и отечественных авторов с применением метода системного и сравнительного анализов, метода статистической обработки данных, теоретического обобщения исследуемых источников.

Современная цифровая банковская система сочетает в себепреимущества Авух составляющих: нового подхода к обслуживанию клиентов и введения эффективной операционной модели оба фактора включены путем оцифровки базовых технологий, процессов и структур. С внешней стороны клиенты извлекают ценовую выгоду с повышенной прозрачностью и сопоставимостью результатов. Выводы исследования показывают, как банки отвечают этим вызовам и потребностям, обеспечивая немедленное, высококачественное взаимодействие, а транзакции выполняются быстро и надежно. При переходе к цифровым технологиям клиенты активно используют большой спектр персонализированных продуктов и услуг, включая финансовые консультации, новые возможности обслуживания и эффективные параметры взаимодействия.

Кмючевые слова: цифровой банк, кибербезопасность, инновационные технологии, финансовый институт, е-банкинг.

\author{
Aubakirova Zh.Y. ${ }^{1}$, Yerdesh E.B. ${ }^{2}$ \\ ${ }^{1}$ doctor of economic sciences, professor, e-mail: aubakyrova.zh@gmail.com \\ ${ }^{2}$ master student, e-mail: yerdesh.elmira@bk.ru \\ al-Farabi Kazakh National University, Kazakhstan, Almaty \\ Digital transformation: \\ banks shift to digitization and innovation
}

The article discusses the digital transformations occurring in the field of finance, which are caused by many common problems and opportunities throughout the industry, whether it concerns insurance, retail, banking or other financial services. At the same time, there are several specific tasks in each of these segments of the financial industry, depending on the level of maturity of the digital transformation of the region, the overall ecosystem, the client's context, including the use of digital channels, the scope of activities and the degree to which digitization occurred and the processes .

The aim of the study is a comparative analysis and generalization of the state of development of digital transformation in the whole world, identifying problems and ways to overcome them. Particular 
attention is paid to the current state and prospects for the development of innovative technologies in the banking sector of the economy in Kazakhstan.

The methodology of the study was based on the study of the works of foreign and domestic authors using the theoretical generalization, system and comparative analysis, the method of statistical data processing.

Ideally, a digital banking system combines the advantages of two components: a new customer look and an efficient operating model - both included by digitizing basic technologies, processes and structures. From the outside, customers benefit from fair prices with increased transparency and comparability. The findings of the study show how banks meet these needs with immediate, high-quality interaction, and transactions are performed quickly and reliably. Customers are actively informed about a large range of personalized products and services, including financial advice, new features and comparative parameters.

Key words: digital bank, cyber security, innovative technologies, financial institution, e-banking.

\author{
Аубакирова Ж.Я. ${ }^{1}$, Ердеш Э.Б. ${ }^{2}$ \\ 'э.Ғ.A., профессор, e-mail: aubakyrova.zh@gmail.com \\ ${ }^{2}$ магистрант, e-mail: yerdesh.elmira@bk.ru \\ әл-Фараби атындағы Қазақ ұлттық университеті, Қазақстан, Алматы қ.
}

\title{
Сандық трансформация:
}

банктердің сандық және инновациямық жүйеге көшуі

\begin{abstract}
Мақалада қаржы салаларында орын алатын цифрлық өзгерістер талқыланады, олар көптеген салаларда, мысалы сақтандыру, бөлшек сауда, банк немесе басқа қаржы қызметтеріне қатысты көптеген жалпы проблемалар мен мүмкіндіктерден туындайды. Сонымен қатар, қаржы секторының осы сегменттерінің әрқайсысында өңірдің цифрлық трансформациясының өтелу деңгейіне, жалпы экожүйеге, клиенттік контекске, оның ішінде цифрлық арналарды пайдалану, қызмет саласы мен цифрлау процесінің дәрежесі мен процестерге байланысты бірнеше нақты міндеттер бар.

Зерттеудің мақсаты - бүкіл әлемдегі цифрлық трансформацияның даму жағдайын салыстырмалы талдау және жалпылау, проблемаларды анықтау және оларды жеңу жолдарын анықтау. Қазақстанда экономиканың банк секторында инновациялық технологияларды дамытудың қазіргі жағдайы мен келешегіне ерекше көңіл бөлінеді.

Зерттеудің әдіснамасы теориялық қорыту, жүйелік және салыстырмалы талдау, статистикалық, деректерді өңдеу әдістемесін қолдану арқылы шетелдік және отандық авторлардың жұмыстарын зерттеуге негізделген.

Ең дұрысы, цифрлық банк жүйесі екі компоненттің артықшылықтарын біріктіреді: жаңа тұтынушы көрінісі және тиімді жұмыс үлгісі - екеуі де негізгі технологияларды, процестер мен құрылымдарды цифрлау арқылы енгізілген. Сыртқы жағынан, тұтынушылар ашықтық, пен салыстырмалылықты арттыру арқылы әділ бағалардан пайда көреді.

Зерттеудің нәтижелері банктердің осы қажеттіліктерді қаншалықты қанағаттандыра алатынын, жоғары сапалы өзара іс-қимылмен, операциялардың тез және сенімді түрде орындалатындығын көрсетеді. Тұтынушылар дербес өнімдер мен қызметтердің кең ауқымы, соның ішінде қаржылық кеңес, жаңа мүмкіндіктер және салыстырмалы параметрлер туралы белсенді түрде хабардар.
\end{abstract}

Түйін сөздер: цифрлық, банк, киберқауіпсіздік, инновациялық, технологиялар, қаржы институты, электрондық, банкинг.

\section{Введение}

Пятый технологический уклад опирается на достижения в области информатики, электронной промышленности, вычислительной техники, программного обеспечения, телекоммуникаций и роботостроении. В Послании Президента Республики Казахстан Н.А. Назарбаева народу Казахстана от 5 октября 2018 г. говорится об усилении процессов мировой политической и экономической трансформации. Новые техно- логии, роботизация и автоматизация усложняют требования к трудовым ресурсам и качеству человеческого капитала. Выстраивается совершенно новая архитектура финансовых систем (http:// www.akorda.kz/ru/addresses/).

Введение системы открытых банковских операций и директивы о платежных услугах ускоряют преобразования в сфере банковских IT-технологий, предоставляя широкую мобильность клиентам. Банки должны предоставлять клиентам возможность делиться своими финан- 
совыми данными, такими, как осуществление расходов и регулярных платежей с уполномоченными сторонними поставщиками. Чтобы ориентироваться в этой безграничной реальности, банки должны обеспечить их цифровое предложение. В связи с этим, современная банковская платформа стремительно меняется.

Удобство, скорость и гибкость больше не считаются привлекательными характеристиками, а стали стандартным ожиданием быстро меняющихся отношений между клиентом и банком. В современном мире успешными организациями будут те, которые смогут идти в ногу с потребностями клиентов и внедрять соответствующие услуги в более широкую экосистему цифровых продуктов. Чтобы преодолеть это, банки должны инвестировать в технологические возможности, которые позволят им стать более динамичными в отношении потребностей клиентов. Они должны включать правильную стратегию, быстро реагировать и вести гибкую политику во всех сферах бизнеса.

Количество устройств, подключенных к интернету и осуществляющих обмен данными, составляет на сегодняшний день 35 млрд. единиц, что в пять раз превышает численность населения мира. На кибератаки и их устранение, явление, получившее широкое распространение с внедрением цифровых технологий, правительства и корпорации разных стран тратят почти полтриллиона долларов США ежегодно. Это одна из причин популярности традиционных методов финансового обслуживания у граждан, не доверяющих новым информационным технологиям.

\section{Материалы и методы}

Методологической основой проведенного исследования являются фундаментальные исследования зарубежных и казахстанских авторов в области цифровой экономики, цифровизации банковской сферы, Государственная Программа «Цифровой Казахстан-2020», Постановление Правительства Республики Казахстан от 12 декабря 2017 года № 827 «Об утверждении Государственной программы «Цифровой Казахстан», Стратегия «Казахстан-2050», а также национальные доклады и глобальные данные в области развития инновационных технологий, опыт стран Западной Европы в реализации программ цифровой экономики.

В статье также рассматриваются вопросы развития IT-рынка в казахстанской экономике.
Инструментом анализа являются статистические исследования банковской сферы. Основным результатом является выявление тренда развития финансового рынка информационных технологий в банковском секторе, следующий этап исследования рассматривает основные направления движения IT-рынка, трансформирующегося в комплексную стратегию его развития. На основе общенаучного метода систематизации эмпирических и теоретических данных, а также метода сравнительного и статистического анализов проводится оценка потенциала перехода казахстанских банков на полную цифровую платформу, готовность потребителя к ожидаемым изменениям.

\section{Обзор литературы}

В проведенном исследовании включены фундаментальные труды зарубежных авторов в области информационных технологий, финансовых технологий, банковских карточных систем, кибербезопасности с точки зрения IT-рынка; моделирование процессов формирования и методов борьбы с киберугрозами. При анализе авторы опирались на данные из Государственной Программы «Цифровой Казахстан-2020», Стратегии «Казахстан-2050», литературу по инновационной деятельности, зарубежный и отечественный опыт IT-технологий в финансовой сфере.

Рассматриваются проблемы и перспективы развития банковского карточного бизнеса в Казахстане. В отличие от многочисленных публикаций по данной тематике, настоящая статья посвящена изучению опыта развития безналичных платежных систем в зарубежных странах, а также России и его успешной адаптации к казахстанским условиям. В статью включены данные зарубежных исследований платежных систем в разные периоды последнего десятилетия (King, 2012; Sinke, 2002; Калистратов, 2009; Ионов, 2015; Голдовский, 2015; Mussel, 2015; Шамраев, 2010; Millner, 2013; Межов, 2012).

В рамках общего вектора глобализации считаем, что стремительное внедрение цифровых технологий, таких как цифровые платформы, платежные системы, финансы (FinTech), может стать эффективным инструментом снижения затрат отдельных субъектов рынка, повышения их конкурентоспособности. Вместе с тем, перед цифровой трансформацией финансового сектора в целом стоит проблема преодоления цифрового неравенства, неразвитой инфраструктуры, дефицита IT-кадров, безопасности и выхода отече- 
ственной и мировой экономики из затягивающего ее глобального кризиса.

Вопросы, касающиеся современного состояния цифровой экономики и перспектив ее развития в условиях глобализации, отражены в статьях авторов (Bouduin, Courbe, 2018; Burnette, 2016).

Создание систем обслуживания продуктов (PSS) со значительными экономическими, экологическими и социальными преимуществами с помощью цифровых технологий описано в (Aris, Daniela, 2017). Процессы усовершенствования банками своих информационных систем, использование инновационных технологий социального трейдинга и робоконсультирования представлены в работе (Гальпер, Кибасов, Никитина, 2017).

Отдельные исследования посвящены вопросам кибербезопасности, с которым связаны такие понятия, как «киберпреступность», «кибертерроризм», «кибервойны». Организация безопасного функционирования национальных информационных инфраструктур будет, скорее всего, определяться соответствующими концепциями кибербезопасности, разработанными практически всеми развитыми странами мира и крупными международными организациями (Казарин, Тарасов, 2013). Развитие механизмов экономической безопасности национальных платежных систем исследуется в работах (Масленников, Федотова, 2017). Следует отметить, что требования безопасности информационных банковских систем в Казахстане регламентируются нормативно-правовыми актами Национального Банка с учетом отраслевых и международных стандартов.

На основе сравнительного анализа внедрения цифровых платформ в финансовом секторе приведены данные о современном состоянии банковских систем Великобритании, Китая, России, Бразилии, Канады, Японии, Германии, США, Италии и др. (Lyons, 2018, Bradford, 2018).

Вопрос о возможном парадоксе роста производительности в цифровой экономике описаны у авторов (Chihiro, Yuji, 2018).

Подробные результаты исследований цифровизации описаны в основной части статьи, а предпосылки и перспективы дальнейшего развития приведены в заключении.

\section{Результаты и обсуждение}

Цифровые технологии и цифровые решения помогают быстро и удобно получать финансо- вые услуги, доступные и простые в использовании - они становятся неотъемлемой частью финансовых учреждений. В ближайшем будущем удастся получить банковское обслуживание удаленно и использовать биометрические технологии. Сегодня в Казахстане быстро развиваются услуги удаленного банковского обслуживания - услуги интернет-банкинга, мобильные банковские приложения, благодаря которым возможно удаленно осуществлять платежи, оплачивать услуги и получать доступ к другим популярным продуктам банков. В этих системах зарегистрировано более 9 миллионов пользователей, из которых около $30 \%$ регулярно осуществляют платежи и переводы. Объем операций через Интернет и мобильные банковские системы уже превышает объем безналичных платежей через POS-терминалы. Ежедневно через цифровую банковскую систему в стране осуществляются транзакции более 400 тысяч раз. Безналичные операции населения превышают сумму в 6 млрд. тенге. 70\% финансовых операций хозяйствующих субъектов также проводятся через электронные банковские приложения (https:// www.kazpravda.kz/fresh/).

Работники финансового сектора, специализирующиеся на новых технологиях, все чаще анализируют практический опыт пользователей, который не соответствует их конкретным ожиданиям. Исходя из этого, главным в успехе банка в цифровой экономике - это данные, которые они накапливают в отношении клиентов, и разумные способы их обработки. Цифровизация и база данных клиентов настолько тесно переплетены, что они не могут функционировать друг без друга. Нам нужно только взглянуть на феноменальные истории успеха корпораций Amazon, Facebook и Google, чтобы понять, как данные о клиенте влияют на клиентский опыт (https:// www.atkearney.com/financial).

Если предположить, что автомобили без водителя и роботы станут частью нашего не столь отдаленного будущего, то будущую банковскую систему с ее собственной формой искусственного интеллекта (ИИ) возможно спрогнозировать. Многие банки уже воспользовались инструментами, поддерживающими искусственный интеллект, такими как чат-боты, заменяющие человека при обслуживании клиентов, но это лишь первые предпосылки нового технологического уклада, который произойдет в финансовом секторе экономики - от виртуальных финансовых помощников до автоматизированного подсчета кредитов. Прогнозный 
анализ технологической замены работы человека имеет огромный потенциал для реорганизации финансовых институтов в беспрецедентных масштабах. Это начало формирования нового направления индустрии финансовых услуг. Во всем мире цифровая революция показывает, как финансовые институты и клиенты стремятся преобразовать свой электронный банк и управлять своими деньгами.

В Западной Европе дирекция платежных услуг устанавливает мировые стандарты интерфейса прикладного программирования (API) для платежей и то же самое происходит в Великобритании. Эти правила были разработаны с учетом повышенной конкуренции, и клиенты имеют больше возможностей контролировать свои деньги дистанционно. Однако появление нового рынка с поддержкой API - это смена программирования платежей, сообщается в докладе издания TheSundayTimes (https://www.raconteur.net/ sponsored). Современные возможности информационных технологий позволят отображать продукты банка и услуги, которые принадлежат крупным финансовым организациям исторически. Это позволит новым провайдерам выйти на рынок и превратить банки в открытые платформы. Существует огромный потенциал для банков по преобразованию своих продуктов и услуг. Открытое банковское обслуживание требует от банков мыслить за пределами собственных потребностей и роста бизнеса, они должны предвосхитить ожидаемые потребности клиентов в новых услугах и оказаться конкурентоспособными для дистрибьюторов.

В последние годы мы наблюдаем, как рост технологий приводит к сдвигу в ожиданиях потребителей. Сегодняшний потребитель в области цифровых технологий рассматривает приложения и веб-сайты как экосистему, поэтому клиенты готовы пользоваться различными альтернативными видами оказания услуг, а индустрия финансовых услуг должна соответствовать этим ожиданиям и предлагать соответствующие продукты и финансовые услуги.

Это особенно относится к поколению Z, которые выросли в эпоху, когда смартфоны, гаджеты и взаимосвязанные с ними устройства становятся повседневными средствами пользования современного человека. Однако старшее поколение, предпочитающее традиционное обслуживание в финансовых учреждениях, будет медленнее принимать изменения.

По данным опроса сайта Bankrate.com было установлено, что $30 \%$ людей в возрасте 18-37 лет считают сберегательные счета лучшими для хранения денег на 10 и более лет. Это намного выше, чем 21\% людей старше 38 лет, которые считают сберегательные счета в электронном виде лучшими для хранения на долгосрочной основе (https://www.bankrate.com/calculators).

Открытый е-банкинг предлагает потребителям много преимуществ, в том числе новые услуги, которые позволят динамично управлять своими деньгами, обеспечат доступ к новым продуктам и возможность управления своими финансами в одном приложении.

Банкам следует учитывать, что лояльные потребители - не постоянное явление. Тенденции меняются, и некоторые клиенты будут мигрировать туда, где лучшие сервисы, независимо от того, где находится основной продукт. Например, клиенты могут использовать новое приложение финансовых технологий, банковский вебсайт и модель дистанционного обслуживания, но текущая учетная запись, которая находится в ее основе, проводится с существующим крупным банком, с которым клиент больше не будет взаимодействовать напрямую.

Прежде всего, банки должны решить, хотят ли они продолжать взаимоотношения с клиентами. Банки содержат огромное количество необработанных данных и информации, но они должны быть более гибкими в том, как они используют его в интересах клиента. Услуги, основанные на цифровых технологиях, предлагают большую вариативность для потребителей и банки должны решить, как будут обрабатывать полученную информацию. Они могут либо формировать партнерские отношения с IT-компаниями, чтобы взять на себя ответственность за пользовательский интерфейс, либо могут сохранить право собственности путем создания собственной платформы.

Швейцарский банк UBS создал цифровой клон своего главного экономиста Даниэля Кальта, который работает на основе искусственного интеллекта. Вскоре цифровой советник начнет встречаться с частными клиентами в Цюрихе (https://prodengi.kz/innovacii). Это практическое применение замены человека роботом обусловлено крупным финансированием как правительства, так и частных инвесторов в искусственный интеллект.

В совокупности эти технологии предоставляют возможности:

- ускорить и упростить обслуживание клиентов и увеличивать доступ к личным данным клиента на самостоятельной основе; 
- обеспечить более глубокое понимание управления рисками, так и перспектив обслуживания клиентов.

- Повысить гибкость и скорость на рынке финансовых приложений.

- Усилить финансовые операции и контроль над ними.

- Обеспечить преобразование институциональных структур и затрат.

По мнению экспертов Всемирного Банка, индекс проникновения финансовых технологий в развитых странах значительно вырос за последние пять лет. Лидерами являются Китай и США. Великобритания и Россия также входят в пятерку лидеров с большим количеством аудитории, активно пользующейся финансовыми технологиями. Основными причинами использования услуг финансовой технологии гражданами являются простота открытия счета и круглосуточный доступ к сервисам (рисунок 1).

С возникновением и активным развитием системы биткойнов и аналогичных ей систем, сформировалось мнение о скором исчезновении банков и полной замене их криптовалютой и новыми финансовыми институтами.

В цифровом банкинге и персональных финансах также действуют некоторые казахстанские проекты. Согласно рейтингу Ассоциации казахстанского интернет-бизнеса и мобильной коммерции (АКИБ) и компании Intervale Kazakhstan, по количеству сессий среди казахстанских интернет-банк-приложений лидирует «Homebank»-продукт «Qazkom» банка, который продолжает работать после слияния c «Halykbank». Среднемесячное количество сессий - 3250 634, из них уникальных пользователей - 84 518. На втором месте расположился «Сбербанк Онлайн Казахстан» - приложение клиентов банка «Сбербанк Казахстан». На третьем месте «Smartbank» - приложение для клиентов Евразийского банка. Четвертое и пятое места поделили «ForteBank» и «ATF24» соответственно (https://forbes.kz/leader/top-30_ mobilnyih).

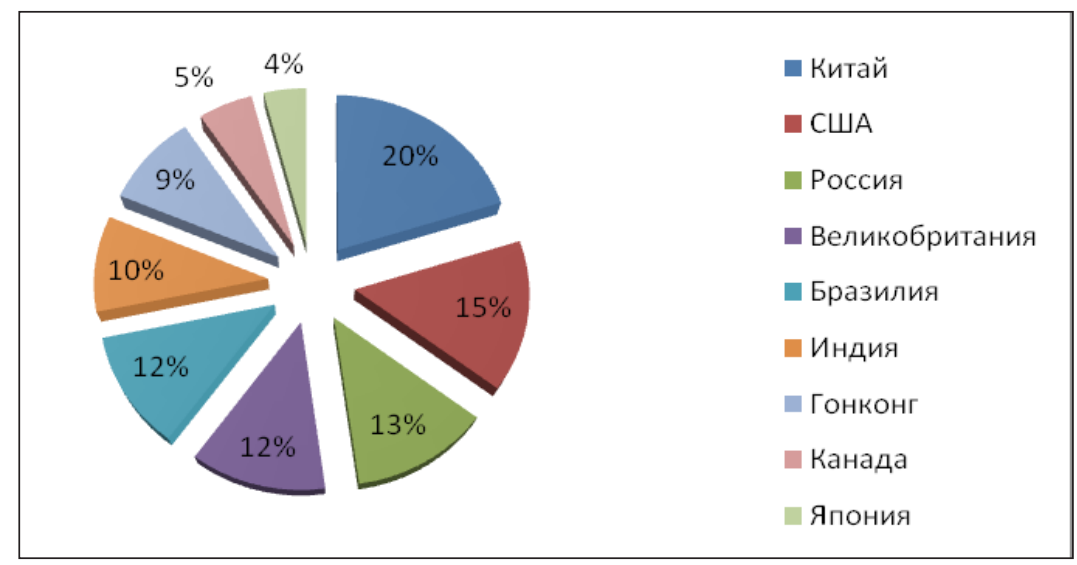

Рисунок 1 - Индекс проникновения финансовых технологий в обзоре стран Источник: Всемирный банк, МБРР, 2017

В Казахстане запущена система мгновенных платежей Suńqar. Данная система позволит проводить мгновенные платежи и переводы денег по Казахстану между клиентами разных банковучастников системы. При осуществлении транзакций между физическими лицами используется номер мобильного телефона, привязанный к платежной карточке, электронному кошельку, текущему банковскому счету.

Услуги в системе Suńqar предоставляются фининститутами через свои мобильные приложения или системы интернет-банкинга. В насто- ящее время этот сервис предоставляют пока три банка. В течение 2019 года более 10 банков планируют подключиться к системе. Новая услуга появится в мобильных приложениях и системах дистанционного обслуживания данных банков по мере доработки своих информационных систем. Тарифная политика по мгновенным платежам и переводам для клиентов определяется фининститутами самостоятельно. По мере развития сервисов, юридические лица и индивидуальные предприниматели также смогут обеспечить прием в свою пользу мгновенных платежей 
за товары и услуги без установки специального оборудования, проводить моментальные выплаты в пользу физических лиц. В частности, с помощью сканирования QR-кодов можно будет расплачиваться мобильным телефоном в розничной торговле.

Внедрение в Казахстане системы мгновенных платежей направлено на предоставление населению и субъектам бизнеса универсальной платформы для проведения платежей в любом месте, в любое время по доступным инструментам оплаты и дистанционным каналам.

Одним из факторов широкого применения инновационных технологий в банковском секторе Казахстана является возможность доступа к высокоскоростному Интернету. Современное состояние отечественных операторов не позволяет добиться равномерного распределения скорости интернет-вещания на всей территории страны, в связи с отсутствием необходимых спутников и станций. Технология 4G LTE была запущена в Казахстане в 2016 г. в крупных городах Казахстана, по причине низкого уровня проникновения устройств, поддерживающих технологию высокоскоростного интернета (https:// kapital.kz/).

Согласно отчету Индекса Глобальной Конкурентоспособности (Global Competitiveness Index), место Казахстана по подписке к широкополосному Интернету заметно улучшилось за последние пять лет, и сейчас Казахстан занимает 54 место в мире (рисунок 2).

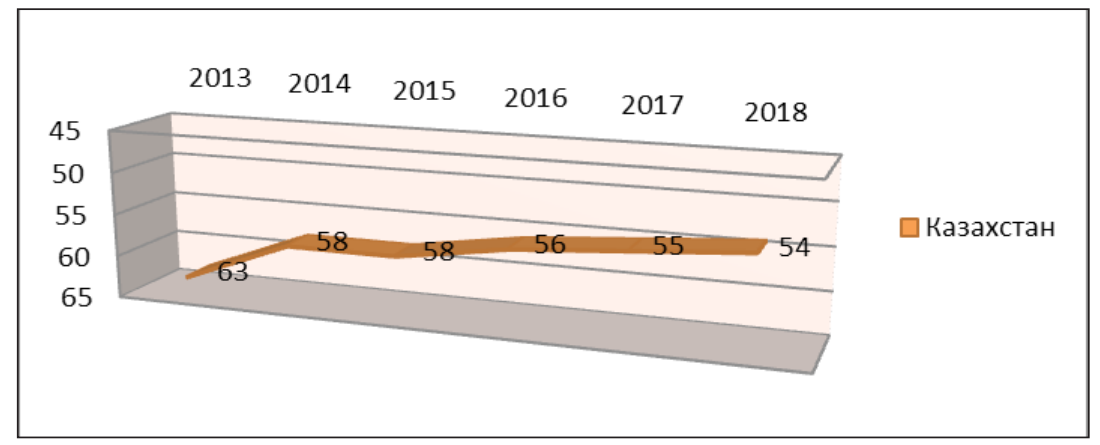

Рисунок 2 - График изменений места Казахстана в GCI по подписке к широкополосному Интернету в период с 2013 г. по 2018 г.

Необходимо добиться максимальной доступности высокоскоростного Интернета во всех секторах экономики, а также установления доступных цен на беспроводный широкополосный Интернет на всей территории страны.

Одним из первых финансовый сектор начал применять роботизацию. Так, по данным Международной федерации роботостроения (International Federation of Robotics - IFR), на долю Японии в декабре 2012 г. приходилось $25,2 \%$ функционирующих в мире промышленных роботов (276 200 ед.) (http://overviewrussia. blogspot.com). В этих условиях банкам необходимо объединять в своей цифровой платформе функции нескольких институтов: платежных систем, финансовых переводов, онлайн-маркета и социальных сетей для обмена информации и данными.

Ещё одним динамично развивающимся мобильным приложением является «Kaspi.kz» от Каспий банка, количество скачиваний которого в AppStore превышает 1 миллион пользователей. Спектр услуг в приложении не ограничивается стандартными банковскими переводами, а включает гибкую платежную систему по более 300 видам платежей разного направления, в том числе платежи в бюджет страны. Данный провайдер имеет собственную маркет площадку Kaspi магазин - платформу для заказа товаров бытовой техники, электроники и прочих товаров в онлайн режиме с доставкой на дом. Это уникальное сочетание маркета и услуг электронного оформления кредита или рассрочки платежей даёт потребителю возможность широкого выбора товаров на сайте. По последним данным, политика банка выдвигает уникальное явление перехода банка к крупной корпорации, объединяющей в себе собственную инфраструктуру для динамичного развития. Произошедшие изменения - ребрэндинг с Kaspibank на Kaspi. kz, трансфер большинства видов переводов с операционной на электронную основу, не остав- 
ляет альтернатив выбора потребителю и ставит необходимость пользования интернет-приложением банка. Перевод части нагрузки с операционной деятельности на самостоятельную основу через приложение в течение одного десятилетия приведет к сокращению числа сотрудников операционной деятельности, тем самым вызвав искусственную волну безработицы в финансовом секторе экономики Казахстана.

Чтобы выжить, когда гиганты, подобные Google, вносят свой вклад в финансовую жизнь людей, банки должны иметь сильную технологическую платформу для конкуренции. Эта платформа - основа цифровой деятельности банков, поддерживаемая четырьмя основными принципами - многоканальный банкинг, интеллектуальный банкинг, модульная банковская деятельность и открытое банковское обслуживание. Каждая из этих четырех платформ является основой успеха в банковской отрасли будущего. Вот что говорит по этому поводу Пиюш Гупта, CEO DBS (Digital Bank of Singapore) банка Сингапура: «Вы измените свой способ оплаты, если найдете более удобный способ обслуживания. Если ваш банк не даст вам надежной альтернативы, вы пойдете к тому, кто более эффективен» (https://www.euromoney.com). Банк связан с ApplePay, SamsungРау и запустил собственный кошелёк PayLah с более чем 800 тыс. пользователями в Сингапуре. Еще лучше DBS развертывает навыки, которые он разработал на развивающихся рынках с гораздо более высоким уровнем населения. Digibank аналогичную систему оплаты DBS запустил в Индии, а также в Индонезии в 2016 году (https://www.euromoney.com).

Кроме того, информация о клиентах была основана на некоторых относительно простых нововведениях, построенных на данных фокусгрупп и опросов. Это были прокси-серверы для реальных индивидуализированных данных о поведении потребителей, результаты которых не получили должного развития. В настоящее время технологические достижения предоставили предприятиям доступ к экспоненциально большему количеству данных о том, какие виды переводов и куда осуществляют пользователи. Это большая возможность для тех, кто может использовать расширенную аналитику, чтобы получить информацию внутри системы (https:// www.pwc.com/gx/en/industries/financial-services).

В банковской системе зарубежных стран руководители финансовых служб знакомы с рисками, киберугрозами, воздействующими на бизнес-процессы. В отчете за 2016 год, назван- ном «Цифровая трансформация в 10 структурных блоках для повышения клиентского опыта и ROE», EFMA (организация финансовой индустрии, способствующая инновациям в розничном банковском обслуживании) $69 \%$ руководителей финансовых служб сообщили, что они крайне обеспокоены киберугрозами, по сравнению с $61 \%$ руководителей во всех секторах (https://www.i-scoop.eu). К сожалению, ситуация вряд ли изменится к лучшему в ближайшие годы из-за следующих факторов, среди них:

1) использование сторонних поставщиков;

2) быстро развивающиеся сложные технологии;

3) трансграничные обмены данными;

4) более широкое использование мобильных технологий клиентами, быстрый рост и распространение Интернета;

5) усиление трансграничных угроз безопасности информации.

Финансовые институты десятилетиями занимаются информационной безопасностью и технологическими рисками. Но все большее число событий, относящихся к кибербезопасности, в последние годы показало, что традиционный подход уже недостаточно эффективен. Фактически, в исследовании PwC Global State of Information Security Survey обнаружили, что в 2016 году было обнаружено 38\% случаев нарушения безопасности, чем год назад (https://www. pwc.com/gx).

Большинство финансовых учреждений попрежнему полагаются на одну и ту же модель информационной безопасности, которую они использовали в течение многих лет. Она ориентирована на контроль и обеспечение безопасности данных бэк-офиса. Однако за последние несколько десятилетий риски информационной безопасности сильно изменились и подход, который финансовые учреждения используют для управления ими, не улучшился.

По прогнозам аналитиков, в 2019 году основное внимание будет уделено повышению кибербезопасности данных, а также смещению приоритетов на инновационные подходы в области финансового регулирования. «Повышение кибербезопасности данных является приоритетом номер один для современных банков. Так, 73\% банков США планируют инвестировать в технологии для смягчения киберугроз», - сообщает Finextra (https://www.mobilearth.com).

Внедряя новые технологические продукты, онлайн банковские системы используют ряд шагов для подтверждения личности всех кли- 
ентов, которые входят в учетные записи. После ввода имени пользователя онлайн-банкинга клиентам предлагается ввести свой пароль. При этом клиенты имеют возможность зарегистрировать свои компьютеры или устройства для дополнительной степени безопасности. Если сеанс онлайн-банкинга клиента остается бездействующим в течение определенного периода времени, система автоматически регистрирует это и завершает сеанс. Это помогает предотвратить доступ неавторизованных пользователей к учетным записям клиентов, если они забывают выйти или оставить свое устройство без присмотра.

Помимо многофакторной аутентификации, банки используют несколько уровней брандмауэров - специальное программное обеспечение, предназначенное для блокирования вредоносных пользователей, вирусов, вредоносных программ и других потенциальных угроз безопасности. Они также используют Secure Sockets Layer (SSL), стандартную технологию безопасности, которая шифрует информацию, отправленную на наш сайт и с нашего сайта. SSL гарантирует, что вся персональная информация, такая как номера кредитных карт, номера социального страхования, номера банковских счетов и учетные данные входа в систему остается конфиденциальной при отправке между веб-сайтами и персональным компьютером, сообщается в докладе Маргарет Бернетт из Nerdwallet (https://www. nerdwallet.com).

Службы безопасности ежедневно проводят мониторинг компьютерных систем, ищут нарушения безопасности и нежелательные вторжения. Кроме того, отделы внутреннего аудита выполняют периодические IT-аудиты вычислительной среды для поиска потенциальных уязвимостей. Наконец, банки регулярно проверяются третьими сторонами для обеспечения надлежащих мер безопасности и работы, как ожидалось. «В любой роли в организации узнавание о безопасности может помочь человеку понять риски и принять обоснованные решения для своих ключевых заинтересованных сторон», - говорит Пави Рамамурти, старший менеджер по информационной безопасности Nationwide (https:// www.nationwide.com).

К сожалению, в казахстанском банковском секторе проблема кибербезопасности не освещена в должной мере. На наш взгляд, следовало бы шире распространять информацию по инвестициям в современные цифровые технологии и платформы, системы защиты от информаци- онных рисков, формирование новых хранилищ данных, а также гибкой IT-инфраструктуры.

\section{Заключение}

В рамках анализа данных отечественных банков, как Halyk Bank, Kaspi Bank, ATF Bank, Сбербанк, выявлено современное их состояние, проблемы и тенденции развития цифровой трансформации в финансовом секторе республики. Количество активных пользователей финансовых услуг растет и перед банками стоит сложная задача - предоставить потребителю динамично развивающийся финансовый продукт цифрового назначения, который будет отвечать требованиям безопасности и полной конфиденциальности.

Результатом данной работы является анализ использования цифровых технологий в банковском секторе Казахстана и зарубежных стран. Большое внимание уделено систематизации и анализу современного состояния, тенденций и перспектив развития финансовых технологий для улучшения сервис-обслуживания банков в Западной Европе, США, Великобритании, Японии и других странах мира, а также применения опыта цифровизации финансовых услуг и операций в отечественной экономике.

В целом, нами подчеркивается, что в Казахстане возможность доступа к широкополосной системе Интернет-ресурсов составляет около $79 \%$, при этом лишь $20 \%$ из них активно пользуются банковскими приложениями для осуществления финансовых переводов и платежей. Иначе обстоит ситуация в Западной Европе, США и Сингапуре, где охват доступа к Интернет-ресурсам значительно выше, соответственно и количество пользователей услуг финансовых технологий возрастает ежегодно.

В ходе исследования подтверждено, что киберугрозы являются одной из главных причин недоверия казахстанского потребителя к цифровой деятельности банков.

В статье приведен опыт зарубежных банков Сингапура и Швейцарии по переходу к полной цифровой системе с внедрением роботостроения. В Казахстане ряд банков на данный момент сосредоточен на разработке и внедрении автоматических банкоматов, заменяющих функции кассира, приложений, электронных касс самообслуживания, системой онлайн заказов карт с доставкой на дом и другие услуги.

По итогам исследования сделан вывод о том, что в странах с развитой системой электронных 
оплат увеличиваются поступления в бюджет от налогов и экономика в целом имеет положительный эффект роста. В результате минимизируются издержки скрытых операций и продаж, идёт полная прозрачность во всех сферах производства и реализации продукции и услуг.

Кроме того, в статье уделено большое внимание нынешнему состоянию внедрения инновационных технологий казахстанских банков. Сделан вывод о необходимости вовлечения инвестиций в цифровую сферу банковских услуг, а также в другие отрасли экономики в соответствии с Программой Правительства «Цифровой Казахстан». Согласно проведенному мониторингу отечественных банков, лишь 20 \% взрослого населения активно пользуются трансфером денежных средств через приложения. Значит эта сфера - свободная зона для широкого развития технологических стартапов по финансовым приложениям.

По затратам на отображение киберугроз приведены меры защиты, применяемые передовыми банками зарубежных стран. Огромные суммы капитала вкладываются правительствами стран и корпораций для защиты и сохранения конфиденциальности клиентской базы данных.

В цифровой трансформации Казахстана на сегодняшний день существует огромное поле для изменений, исследований и охвата новой аудитории пользователей, возможность внедрения инвестиций в эту сферу. Создание новых цифровых продуктов с использованием искусственного интеллекта и систем защиты информации - задача долгосрочная, системная, затрагивающая всю банковскую инфраструктуру и бизнеспроцессы.

\section{Литература}

Послание Президента Республики Казахстан Н. Назарбаева народу Казахстана, 5 октября 2018, http://www.akorda. kz/ru/addresses/addresses_of_president/poslanie-prezidenta-respubliki-kazahstan-nnazarbaeva-narodu-kazahstana-5-oktyabrya$2018-\mathrm{g} 018$ г.

Banking in a digital world, https://www.atkearney.com/financial-services/article?/a/banking-in-a-digital-world

Lens L. Digitalization is driving the future of banking, https://www.raconteur.net/sponsored/digitalisation-driving-future-banking

Журнал Экономичный калькулятор, https://www.bankrate.com/calculators/index-of-checking-savings-calculators.aspx

Petters B. Investor's business daily, https://prodengi.kz/innovacii_v_bankah/kak-banki-s-uoll-strit-prevrawayutsya-v-botov/

Всемирный Банк, МБРР, http://www.worldbank.org/

Рейтинг Forbes Kazakhstan, Топ-30 мобильных приложений Казахстана, https://forbes.kz/leader/top-30_mobilnyih_prilojeniy_kazahstana_-2018_1539048058/

Piyush G. World's best digital bank 2018: DBS https://www.euromoney.com/article/b18k8wtzv7v23d/world39s-best-digitalbank-2018-dbs

DBS bank, www.euromoney.com/article/b163mv0dk41x45/dbs-top-of-the-digital-class

Courbe J., Lyons J. Financial services technology 2020 and beyond: Embracing disruption https://www.pwc.com/gx/en/industries/financial-services/publications/financial-services-technology-2020-and-beyond-embracing-disruption.html

Consumer/retail banking: digital transformation, optimization and digitization, https://www.i-scoop.eu/retail-banking-digitaltransformation/

Запуск сети 4G, https://kapital.kz/business/53233/ksell-zapustil-set-4g-lte.html

Omni-Channel Banking, https://www.mobilearth.com/mobile-banking-news/digital-transformation-banks-digitization-2018

Burnette M. Is Online Banking Safe? How to Boost Your Banking Security, https://www.nerdwallet.com/blog/banking/onlinebanking-security/

Банковская защита и безопасность, https://www.nationwide.com/customer-banking-protection-security.jsp

Bradford L. What you need to know about cybersecurity in 2018, https://www.forbes.com/sites/laurencebradford/2018/03/30/ why-people-should-learn-about-cybersecurity-in-2018/

Госпрограмма «Цифровой Казахстан» утверждена постановлением Правительства РК №827 от 12.12.2017

Закон Республики Казахстан от 31 августа 1995 года № 2444 «О банках и банковской деятельности в Республике Казахстан» Глава 7-1.

Бретт К. Банк 3.0. Почему сегодня банк - это не то, куда вы ходите, а то, что вы делаете. - 2012

Муссель К.М. Платежные технологии, системы и инструменты. - 2015

Новые технологии развивают рынок платежных услуг. - 2017, https://www.kazpravda.kz/fresh/view/novie-tehnologii-razvivaut-rinok-platezhnih-uslug

Масленников В.В., Федотова М.А., Сорокин А.Н. Новые финансовые технологии меняют наш мир // Финансы: Теория и Практика. - 2017. - №2, https://cyberleninka.ru/article/n/novye-finansovye-tehnologii-menyayut-nash-mir

Никитина Т.В., Никитин М.А., Гальпер М.А., Кибасов В.В. Финансовые технологии в области инвестирования // Известия СПбГЭУ. - 2017. - №3 (105), https://cyberleninka.ru/article/n/finansovye-tehnologii-v-oblasti-investirovaniya 
Chihiro W., Yuji T., Pekka N. Measuring GDP in the digital economy: Increasing dependence on uncaptured GDP // Technological Forecasting and Social Change. - 2018, https://www.sciencedirect.com/science

Aris P., Daniela C.A. The Emergent Role of Digital Technologies in the Circular Economy: A Review // Procedia CIRP. - 2017. - vol. 64, pp. 19-24, https://www.sciencedirect.com/science/article/pii/S2212827117301452 2017

\section{References}

Aris P., Daniela C.A. (2017) The Emergent Role of Digital Technologies in the Circular Economy: A Review. Procedia CIRP, vol. 64, pp. 19-24, https://www.sciencedirect.com/science/article/pii/S2212827117301452 2017

Banking in a digital world, https:/www.atkearney.com/financial-services/article?/a/banking-in-a-digital-world

Bankovskaya zaschita i bezopasnost [Banking Protection and Security], https://www.nationwide.com/customer-banking-protection-security.jsp

Bradford L. What you need to know about cybersecurity in 2018, https:/www.forbes.com/sites/laurencebradford/2018/03/30/ why-people-should-learn-about-cybersecurity-in-2018/

Brett K. (2012) Bank 3.0. Pochemu segodnya bank - eto ne to, kuda vyi hodite, a to, chto vyi delaete [Bank 3.0. Why today a bank is not where you go, but what you do]

Burnette M. Is Online Banking Safe? How to Boost Your Banking Security, https://www.nerdwallet.com/blog/banking/onlinebanking-security/

Chihiro W., Yuji T., Pekka N. (2018) Measuring GDP in the digital economy: Increasing dependence on uncaptured GDP. Technological Forecasting and Social Change, https://www.sciencedirect.com/science

Consumer/retail banking: digital transformation, optimization and digitization, https://www.i-scoop.eu/retail-banking-digitaltransformation/

Courbe J., Lyons J. Financial services technology 2020 and beyond: Embracing disruption, https://www.pwc.com/gx/en/industries/financial-services/publications/financial-services-technology-2020-and-beyond-embracing-disruption.html

DBS Bank, https://www.euromoney.com/article/b163mv0dk41x45/dbs-top-of-the-digital-class

Gosprogramma «TsifrovoyKazahstan» utverzhdena postanovleniem Pravitelstva RK \#827 ot 12.12.2017 [The state program «Digital Kazakhstan» was approved by the Government of the Republic of Kazakhstan No. 827 of 12/12/2017] ing

Lens L. Digitalization is driving the future of banking, https://www.raconteur.net/sponsored/digitalisation-driving-future-bank-

Maslennikov V.V., Fedotova M.A., Sorokin A.N. (2017) Novyye finansovyye tekhnologii menyayut nash mir [New financial technologies are changing our world]. Finansy: Teoriya i Praktika, vol. 2, https://cyberleninka.ru/article/n/novye-finansovyetehnologii-menyayut-nash-mir

Mussel K.M. (2015) Platezhnyie tehnologii, sistemyi i instrumentyi [Payment technologies, systems and tools]

Nikitina T.V., Nikitin M.A., Gal'per M.A., Kibasov V.V. (2017) Finansovyye tekhnologii v oblasti investirovaniya [Financial technologies in the field of investment]. Izvestiya SPbGEU, vol. 3 (105), https://cyberleninka.ru/article/n/finansovye-tehnologii-voblasti-investirovaniya

Novyie tehnologii razvivayut ryinok platezhnyih uslug (2017) [New technologies develop the payment services market], https:// www.kazpravda.kz/fresh/view/novie-tehnologii-razvivaut-rinok-platezhnih-uslug

Official website of World Bank, http://www.worldbank.org/

Omni-Channel Banking, https://www.mobilearth.com/mobile-banking-news/digital-transformation-banks-digitization-2018

Petters B. Investor's business daily https:/prodengi.kz/innovacii_v_bankah/kak-banki-s-uoll-strit-prevrawayutsya-v-botov/

Piyush G. World's best digital bank 2018: DBS https://www.euromoney.com/article/b18k8wtzv7v23d/world39s-best-digitalbank-2018-dbs

Poslanie Prezidenta Respubliki Kazahstan N. Nazarbaeva narodu Kazahstana [Message of the President of the Republic of Kazakhstan N.Nazarbayev to the people of Kazakhstan], 5.10.2018, http://www.akorda.kz/ru/addresses/addresses_of_president/ poslanie-prezidenta-respubliki-kazahstan-nnazarbaeva-narodu-kazahstana-5-oktyabrya-2018-g018 г. //

Reyting Forbes Kazakhstan, Top-30 mobilnyih prilozheniy Kazahstana [Rating Forbes Kazakhstan, Top-30 mobile applications of Kazakhstan], https://forbes.kz/leader/top-30_mobilnyih_prilojeniy_kazahstana_-_2018_1539048058/

Zakon Respubliki Kazahstan ot 31 avgusta 1995 goda 2444 «O bankah i bankovskoy deyatelnosti v Respublike Kazahstan» Glava 7-1 [Law of the Republic of Kazakhstan of August 31, 1995 No. 2444 «On Banks and Banking Activities in the Republic of Kazakhstan» Chapter 7-1]

Zapusk seti 4G [4G network launch], https://kapital.kz/business/53233/ksell-zapustil-set-4g-lte.html

Zhurnal Ekonomichnyiy kalkulyator [Journal Economic Calculator], https://www.bankrate.com/calculators/index-of-checkingsavings-calculators.aspx 